\title{
Early and late complications after gastric bypass: A literature review
}

\author{
V. O. Nevmerzhytskyi \\ Bogomolets National Medical University, Kyiv \\ \ Viktor Nevmerzhytskyi: vnsurgeon@ukr.net \\ V.O. Nevmerzhytskyi, http://orcid.org/0000-0003-1427-9498
}

Over the last few decades, excess weight and obesity have become a considerable health problem that has a lasting impact on communities worldwide. According to the WHO, about 1.9 billion people over the age of 18 are overweight [32]. Obesity accounted for about 4.7 million premature deaths in 2017. Globally, obesity was associated with an increase in mortality rate from $4.5 \%$ in 1990 to $8 \%$ in 2017 [32]. Bariatric surgery is currently recognized as the most effective treatment option for morbid obesity. Over the past 10 years, gastric bypass surgery has proved more effective than any other surgical methods due to its optimal metabolic effects.

The aim of the review is to carry out an analysis of literature data in order to identify main complications after gastric bypass in patients with obesity.

The complication rate after bariatric surgery decreased from $10.5 \%$ in 1993 to $7.6 \%$ in 2006 [3]. The mortality rate after bariatric surgery was $0.08 \%$ within 30 days after surgery and $0.31 \%$ after 30 days [13]. According to the BOLD study (2010), for 57,918 bariatric operations, the complication rate was 6,240 (10.77\%) and the mortality rate was 78 (0.135\%), within 30 days after surgery - 0.089\%, within 90 days after surgery - 0.112\%. Roux-en-Y Gastric Bypass (RYGB) was carried out in 30,864 cases, and 4,588 (14.87\%) patients developed postoperative complications. Early complications include anastomotic leaks (0-5,6\% for laparoscopic approach and 1,6-2,6\% - for laparotomy), small bowel obstruction caused by a blood clot ( $0-0,5 \%)$, bleeding from the sutures (1,5\%), and thromboembolic complications (0,2-5\%). Late complications include stenosis of the gastrointestinal tract (3-27\%), marginal ulceration (MU) - 0,6-16\%, an incarcerated Petersen's space hernia $-2,51 \%$, perforation of the stomach and small intestine ( $1-2 \%$ ), gastrogastric fistula formation - 1,5-6,0\%, weight regain (to 17,1\%).

Increasing global demand for bariatric surgery as the best option for the management of excess weight and obesity necessitates more detailed investigation of possible complications it may induce. Therefore, further research is required to develop and study new effective methods for prevention and treatment of complications after surgical treatment of patients with morbid obesity.

\section{KEYWORDS}

obesity, bariatric surgery, gastric bypass, anastomotic leaks, small bowel obstruction, marginal ulceration, Petersen's space hernia, gastrogastric fistula, weight regain.

AR'TICLE • Received 2021-11-01 • Received in revised form 2021-11-18

(C) General Surgery, 2021

Over the last few decades, excess weight and obesity have become a considerable health problem that has a lasting impact on communities worldwide. According to the WHO, about 1.9 billion people over the age of 18 are overweight [32]. Obesity accounted for about 4.7 million premature deaths in 2017. Globally, obesity was associated with an increase in mortality rate from $4.5 \%$ in 1990 to $8 \%$ in 2017 [32]. Bariatric surgery is currently recognized as the most effective treatment option for morbid obesity. Over the past 10 years, gastric bypass (GBP) surgery has proved more effective than any other surgical methods due to its optimal metabolic effects.
According to the latest global statistics, presented in the statistical report «Fifth IFSO Global Registry Report 2019», which included data from 61 countries, 833,687 bariatric operations were performed between 2014 and 2018. However, a respective structural analysis was carried out for the period 2015-2018. It showed that 520,983 bariatric operations were performed within this time frame, including 305,242 (58.6\%) operations done as a sleeve gastrectomy, 162,613 (31.2\%) gastric bypass surgeries, 21,613 (4.1\%) mini-gastric bypass surgeries, 19,255 (3.7\%) gastric banding procedures and $8,665(1.7 \%)$ other surgical interventions. The vast 
majority of operations (99.1\%) were conducted using laparoscopic abdominal access technique [13].

The complication rate after bariatric surgery decreased from $10.5 \%$ in 1993 to $7.6 \%$ in 2006 [3]. The mortality rate after bariatric surgery was $0.08 \%$ within 30 days after surgery and $0.31 \%$ after 30 days [13]. According to the BOLD study (2010), for 57,918 bariatric operations, the complication rate was $6,240(10.77 \%)$ and the mortality rate was $78(0.135 \%)$, within 30 days after surgery $0.089 \%$, within 90 days after surgery $-0.112 \%$. Roux-en-Y Gastric Bypass (RYGB) was carried out in 30,864 cases, and 4,588 (14.87\%) patients developed postoperative complications [24].

Early complications include anastomotic leaks, small bowel obstruction caused by a blood clot, bleeding from the sutures, and thromboembolic complications [9].

Late complications include stenosis of the gastrointestinal tract, gallstone disease, marginal ulceration (MU), an incarcerated Petersen's space hernia, intussusception, perforation of the stomach and small intestine, gastrogastric fistula (GGF) formation, weight regain, lack of vitamins and microelements [6].

According to various statistical data, anastomotic leakage (AL) after gastric bypass surgery is $0-5.6 \%$ for laparoscopic GBP and $1.6-2.6 \%$ for open GBP. In specialized bariatric centers, this variable reaches $1.5 \%[1,6,19,23,32]$.

According to the day of appearance, AL can be divided into early (within 4 days after surgery), medium-term (between day 5 to 9 after surgery), late (after 10 or more days) [19, 24, 52]. According to the severity, AL can be graded as type I, which is manifested by a small defect with or without minor systemic disorders, and type II, which is diagnosed when large defects with systemic manifestations or air-fluid accumulation in the abdominal cavity are observed. Anastomotic leaks can be localized around the sites of the gastrojejunal anastomosis (53.3\%), staple lines on the gastric pouch $(18.3 \%)$, staple lines in the place of the jejunal transection $(15.0 \%)$, the jejunojejunal anastomosis (5.5\%) and staple lines on the excluded gastric remnant (1.7\%) [19]. The development of AL is influenced by mechanical and ischemic factors that interfere with the normal healing process. However, another complicating factor is associated with an increase in pressure within the stomach and small intestine, which results in greater tension along the suture [42, 67]. Other factors that may contribute to the development of this complication are advanced age over 50 years, male gender, $\mathrm{BMI}>50 \mathrm{~kg} / \mathrm{m}^{2}$ and previous bariatric surgery [28]. Anastomotic leaks that appear in the first
5 days after surgery are most often linked to the application of improper operation technique, and those that develop after 5 days are most likely the result of local ischemia or infection [5]. To prevent the occurrence of AL, various techniques are currently used for suture reinforcement with fibrin sealant [9]. An important factor that reduces the incidence of $\mathrm{AL}$ is the experience of the surgeon. The study of L. ElKadre et al. (2013) that included 2,281 patients, who underwent laparoscopic RYGB, revealed that after 500 surgical procedures, the operation time and postoperative complication rates reduced. The mortality rate was $0.43 \%$, the main cause of death was pulmonary embolism and AL (0.14\% each) [26].

Surgery is the gold standard of AL treatment. Surgical treatment includes restoration of the gastrointestinal tract integrity, drainage of the abdominal cavity and prevention of future complications [32]. Endoscopic interventions are used in both the diagnosis and treatment of AL. The endoscopic therapy includes stent placement at the defect site, defect clipping, AL site drainage, Vacuum-Assisted Closure therapy, and fibrin sealant injections [66]. During endoscopic interventions, the technique of vacuum-associated endoscopic drainage is also used. A nasogastric tube with a sponge at the distal end, which is fixed with sutures, is inserted. An endoscopic device is guided into the lumen of the organ to place the sponge in it. Then a negative pressure is created in the area of the defect through the nasogastric tube to allow the sponge to absorb fluid and remnants of the non-viable tissue. The pressure ranges from -125 to $-75 \mathrm{~mm} \mathrm{Hg}$. The sponge should be changed every $3-4$ days $[37,8]$. The level of full resolution is from $85 \%$ to $100 \%$ [37].

Acute mechanical bowel obstruction (BO) caused by a blood clot is very rare (up to $0.5 \%$ ) after laparoscopic RYGB. The most common localization of $\mathrm{BO}$ is the site of the jejunojejunal anastomosis. Most obstructions occur $2-5$ days after surgery. Computed tomography of the abdominal cavity is the main method of diagnosing bowel obstruction, including BO arising from a blood clot [35]. On radiography of the organs of the abdominal cavity, there are signs of intestinal obstruction, and the contrast study of the gastrointestinal tract allows detecting the distention of the stomach and jejunal loops [60]. In the cases described in the meta-analysis, patients underwent relaparotomy with enterotomy and removal of a blood clot from the lumen [53].

Postoperative bleeding after GBP occurs in $1.5 \%$ of patients and is associated with high mortality, increased hospital stays, and other complications [76]. Bleeding events are observed around the sites of the gastric pouch $(30 \%)$, the excluded 
gastric remnant (40\%), and the jejunojejunal anastomosis (30 \%) [36]. Postoperative bleeding events after GBP are identified as early and late (up to 30 days and after 30 days from the time of surgery). From all bleeding events after RYGB, early bleeding accounts for $71.4 \%$ of all cases and usually appears after 3.2 days. $43 \%$ of bleeding events occur within 24 hours after surgery [36].

About $80 \%$ of acute postoperative bleeds in patients after bariatric surgery stop on their own and don't require any medical attention [32]. Immediate administration of proton pump inhibitors is indicated for patients with bleeding into the stomach or intestine [6]. The patients with severe bleeding require urgent surgical intervention. Endoscopic, laparoscopic or open access techniques are used. If the source of bleeding is in the organ cavity and is accessible for endoscopic treatment, clipping or epinephrine injection is performed. The use of electrosurgery is not recommended due to the high risk of perforation in the late period [29]. Indications for surgery are impaired hemodynamics of the patient, bleeding into the abdominal cavity, the bleeding site is inaccessible for endoscopic treatment, or the endoscopist doesn't have appropriate skills and training in endoscopic hemostasis techniques.

Both laparotomy and laparoscopy are used. The main mission of the surgeon is to find the source of bleeding, evacuate hematoma and perform hemostasis [29]. Angioembolization of the left gastric artery has been used in isolated studies to stop bleeding, but due to the high risk of the gastric pouch ischemia, it is recommended only in case of ineffective endoscopic treatment in patients with severe course and contraindications for reoperation [30].

Internal herniation (IH) after RYGB occurs in about $2.51 \%$ of patients. Symptoms most often appear between 16-35 months [31]. According to the location, hernias are most frequently detected in the mesentery of the colon (69.0\%), Peterson's space $(18.0 \%)$, and at the site of the jejunojejunal anastomosis $(14.4 \%)$. The mortality rate is $1.17 \%$. The major risk factor for internal herniation is rapid weight loss [32]. The studies indicate a reduction in IH if the mesenteric defects are closed. The mesenteric defects are described as the places of the main localization of IH. They include a defect in the mesentery of the colon, which is formed during surgery and through which the alimentary loop passes, Peterson's space, which occurs between the mesentery of the alimentary and biliopancreatic loops after the jejunal loop transection and mobilization, as well as jejunal defect, which can develop at the site of the side-to-side jejunojejunal anastomosis which is constructed by suturing the efferent loop to the afferent loop with interrupted sutures [9]. N. Geubbels et al. (2015) state that the best option is the antecolic procedure with closure of all defects (Petersen's space, jejunal defect) that reduces the incidence of IH (1.0\%) [33]. Clinically, the most common manifestation was abdominal pain after meal and it was noted in $24(53.4 \%)$ patients. Abdominal pain syndrome with nausea was seen in $8(17.8 \%)$ patients. Abdominal pain syndrome with nausea and vomiting was observed in $8(17.8 \%)$ patients. Acute abdominal pain was present in $2(4.4 \%)$ patients. Acute abdomen was noted in $1(2.2 \%)$ patient [38]. Amylase/lipase levels were higher in patients with acute obstruction than in patients with chronic symptoms (64\% vs. $28 \%$ ). Patients with biliopancreatic loop obstruction also had more elevated levels of amylase/lipase than patients without obstruction ( $65 \%$ vs. $21 \%$ ). The most elevated levels were observed in acute obstruction of the biliopancreatic loop (94\%) compared with acute alimentary obstruction (27\%). It is evidence of the existing link between increased amylase/lipase levels and acute obstruction of the biliopancreatic loop [70]. Instrumental examinations include abdominal radiography and computed tomography of the abdominal cavity. M. S. Altieri et al. (2015) developed an algorithm for diagnosing IH in patients after RYGB. The study included 52 patients with IH. The findings of the study showed that the sensitivity of CT for the diagnosis of IH was $76 \%$, specificity was $60 \%$. However, when the blood neutrophil levels were included into the evaluation process, the sensitivity increased to $96 \%$ [48].

The onset of symptoms of intestinal obstruction due to IH requires immediate surgical treatment. Laparoscopic access is used at an early stage, when there is no significant distention of the intestinal loops. Laparotomy is recommended in case of severe peritonitis. Typical IH sites should be checked. If a hernia is found, it is fixed, and the defect is closed with a continuous or non-absorbable purse-string suture. When strangulation occurs, resection of the unviable part of the intestine is performed with the formation of anastomosis [16, 57].

Gastro-gastric fistulas occur in 1.5-6.0\%. The causes of fistulas are insufficient transection of the stomach, tissue ischemia, leakage of intestinal contents into the excluded gastric remnant, the presence of foreign objects (catgut and staples, improper suturing) [40]. Gastro-gastric fistulas usually form 25 days after a diagnosed gastrojejunal anastomotic failure. Gastro-gastric fistulas are classified as type 1 that are located at a distance of $2 \mathrm{~cm}$ from the gastrojejunal anastomosis, and type 2 that are located at a distance of less than $2 \mathrm{~cm}$ from the 
gastrojejunal anastomosis [10, 62]. L. Carrodeguas et al. (2005) identified 6 main causes of Gastro-gastric fistulas, including iatrogenic (incomplete gastric transection, presence of perigastric fat included in the transected tissue), gastrojejunal anastomotic leaks, technical reasons, gastric wall tissue migration after surgery, ulceration and perforation, foreign body erosion resulting from the placement of preanastomotic rings to prevent dilatation of the anastomosis [10].

The tactics of treatment of patients with GGFs include observation, conservative treatment, surgery or endoscopic intervention. Observations are recommended for patients with Gastro-gastric fistulas, which are accidentally found and do not cause any discomfort [9]. Indications for surgical treatment are ineffectiveness of conservative treatment, worsening of symptoms that reduces the quality of life of patients, weight gain or insufficient weight loss, gastrointestinal bleeding associated with ulcers, large Gastro-gastric fistulas [9]. The tactics depend on the postoperative period, the cause, the presence of the ulcer, and the patient's general condition. The type 1 Gastro-gastric fistulas require transection of the fistula tract that is carried out vertically to the gastrojejunal anastomosis. The type 2 Gastro-gastric fistulas necessitate full resection of the fistula tract and the gastrojejunal anastomosis which is followed by the formation of a new anastomosis [62]. Laparoscopic access is more optimal than laparotomy if the operation is initially performed laparoscopically, and Gastro-gastric fistulas are diagnosed at an early stage, as late diagnosis reveals the distorted anatomy due to inflammation and adhesions [18, 30]. Large Gastro-gastric fistulas require surgical removal of the excluded gastric remnant together with the fistula tract $[18,64]$. Endoscopic obturation of the fistula tract opening is performed by using fibrin sealant, suturing of the opening, and clipping [9, 29, 55].

Marginal ulceration is a defect of the mucous membrane that penetrates through its muscular layer around the sites of the alimentary loop, the gastric pouch or excluded gastric remnant. They occur in $0.6-16.0 \%[58,15]$. of patients after laparoscopic RYGB, a certain number of patients with asymptomatic ulcers should also be taken into account. In a study by A. Csendes et al. (2009), 315 patients underwent Esophagogastroduodenoscopy 1 month and 17 months after laparoscopic RYGB. Marginal ulceration was diagnosed in 25 patients $(6.0 \%)$ after 1 month, 7 of whom were asymptomatic. After 17 months, only 1 new ulcer and 1 recurrent ulcer were diagnosed after Proton-pump inhbitor therapy [20]. From $9 \%$ to $33 \%$ of patients with MU require surgical treatment [58, 20, 11]. Marginal ulcers complicated by perforation are found in about $1-2 \%$ of patients after RYGB, whereas $20 \%$ of MU turn out to be complicated by perforation [15]. They most commonly occur between 3 and 24 months after surgery. About $20 \%$ of perforations occur in patients with asymptomatic MU, and risk factors are nonsteroidal anti-inflammatory drug, smoking, and glucocorticosteroids [27]. The treatment is surgical, open or laparoscopic, with drainage of the abdominal cavity and suturing of the defect. In the group operated laparoscopically, 1 patient developed hydrothorax, which required drainage under ultrasound control. In the group of laparotomies, 1 patient developed pulmonary embolism, and 1 patient died of sepsis and multiple organ failure [39].

About $5 \%$ of ulcers that form after laparoscopic RYGB are complicated by bleeding, with acute massive bleeding developing in $1.1-4.0 \%[25,54]$. Administration of anticoagulants or antiplatelets increases the risk. Conservative tactics include intravenous access, infusion therapy, and transfusion if needed. Insertion of a nasogastric tube is avoided. Urgent EGD is recommended if the patient has stable hemodynamics, with clipping or epinephrine injection. The rate of re-bleeding after EGD is $22 \%$ and $4 \%$ of them require surgery [73].

Stenosis after gastric bypass procedure usually occurs in $3-27 \%$ of patients $3-4$ weeks after surgery [14, 21, 69, 34, 43]. After laparoscopic RYGB, strictures and stenoses are most frequently found at the site of the gastrojejunal anastomosis. Risk factors for the anastomotic stricture after laparoscopic RYGB are advanced age over 60 years, circular staple suture, postoperative anastomotic failure and ulcer formation. In a meta-analysis of $\mathrm{H}$. Khalayleh et al. (2018), there is evidence of more frequent development of the anastomotic stricture after using a circulatory stapler [41].

The treatment includes endoscopic balloon dilatation of the stricture. It is recommended to use a balloon with a diameter of up to $18 \mathrm{~mm}$ during the first dilatation. The use of balloons of larger diameter can cause rapid emptying of the gastric pouch and lack of effect from the operation $[46,69]$. The longer the postoperative period $(\mathrm{p}=0.007)$ and the smaller the diameter are after the first dilatation $(p=0.015)$, the lower dilatation efficiency is achieved. Perforations occurred in 3 patients $(1.8 \%)$ after conservative treatment [21]. According to a cohort study of 36,362 patients after RYGB, registered in the Scandinavian Registry of Bariatric Surgery, the gastrojejunal anastomotic stricture occurred in 101 patients within 1 year after surgery. Risk factors were defined as advanced age over 60 years OR - $6.2(95 \% \mathrm{CI}$ 2.7-14.3), use of a circular stapler for the formation 
of the gastrojejunal anastomosis OR -2.7 (95\% CI $1.4-5.5)$, postoperative insufficiency of the anastomosis OR - 8.9 (95\% CI 4.7-17.0), the presence of marginal ulcers OR - 30.0 (95\% CI 19.2-47.0). $75 \%$ of strictures were diagnosed within the first 70 days after surgery. Two or fewer endoscopic dilatations were $50.0 \%$ effective. Perforations occurred in $10.0 \%$ of patients during dilatation. In general, the risk of perforation during endoscopic dilatation is $3.8 \%$ [4]. $38.0 \%$ of patients require more than 1 endoscopic dilatation. The complication rate after dilatation is $4.0 \%$. In the case of refractory stricture, steroid injections are used before dilatations. In case of perforations, it is recommended to carry out conservative treatment, and stents are used for large perforations [7]. For chronic refractory strictures found before dilatations, stents have been used in isolated studies. The authors recommend the placement of stents only in patients with severe strictures as part of preparation for surgical treatment $[61,12,74]$.

After bariatric intervention during the first 18-24 months, patients have the «honeymoon» period, when they experience weight loss. Most patients subsequently stop losing weight and gradually gain weight. According to various studies, weight gain occurs $2-5$ years after surgery $[45,49,17]$.

Some researchers consider weight gain as the difference between the highest and lowest body weight after surgery; increase in Body Mass Index; $\% \mathrm{EWL}=$ lost body weight $(\mathrm{kg})$ : overweight $(\mathrm{kg})$. 100 , or the difference between the weight before and after the operation expressed as a percentage $[5,75$, 47]. Weight gain occurs in about $20 \%$ of patients after laparoscopic RYGB [65, 22, 51]. In the study, weight gain of more than $10 \%$ of the lowest body weight in the postoperative period was recorded in $24 \%$ of patients [75]. In a 2007 study, from 782 patients, weight gain was noted in $46 \%$ two years after surgery and in $64 \% 4$ years after surgery [49]. Comparing weight 1 and 2 years after surgery, a $5 \%$ increase was identified in $33 \%$ of patients [71]. The review of 16 scientific studies allowed classifying of the causes of weight gain into 5 groups: eating disorders, psychological problems, endocrine or metabolic disorders, physical inactivity and anatomical surgical factors [63].

Due to the negative psychological and physical impact of weight regain, revisional bariatric surgeries are recommended 1 year after surgery, but it should be borne in mind that the risk of postoperative complications for secondary bariatric surgeries is higher than for the primary procedures [63]. The review of 24 studies showed that 866 patients had significant weight loss in the early period after revisional bariatric surgery, which followed unsuccessful RYGB. Secondary bariatric surgery was performed with the application of 5 different techniques, but only 3 of them, including biliopancreatic shunting, distal gastric bypass and gastric banding, led to weight loss with a low incidence of complications. Endoluminal interventions and creation of a new Roux loop are not recommended [72]. Endoscopic techniques that are widely used nowadays include Apollo OverStitch (Apollo Endosurgery, Austin, Texas), which is the formation of a fold and reduction of the gastrojejunal anastomosis diameter, and sclerotherapy and OTSC (Over-The-Scope-Clip) clipping, in which special clips are used to reduce the gastrojejunal anastomosis diameter [44]. Sclerotherapy is performed by injecting a sclerosant, usually Morrhuate Sodium, into the tissue at the site of the gastrointestinal anastomosis to increase the restrictive effect. The study shows that $91.6 \%$ of patients lose weight 1 year after injection [44].

Thus, increasing global demand for bariatric surgery as the best option for the management of excess weight and obesity necessitates more detailed investigation of possible complications it may induce. Therefore, further research is required to develop and study new effective methods for prevention and treatment of complications after surgical treatment of patients with morbid obesity.

\section{DEClARATION OF INTERESTS}

The author declare no conflicts of interest.

Funding. The work is a fragment of the planned research work of the Department of General Surgery No2 of Bohomolets National Medical University «Implementation of minimally invasive surgical techniques in the treatment of pathologies of the abdominal cavity, anterior abdominal wall, morbid obesity by fast-track technique» (State registration number $0118 \mathrm{U} 000147$ ).

\section{REFERENCES}

1. Afaneh C, Dakin GF. Enteric leaks after gastric bypass: prevention and management, in bariatric surgery complications and emergencies. In: Herron DM, editor. Springer, Switzerland 2016. p. 81-9.

2. Almby K, Edholm D. Anastomotic Strictures After Roux-en-Y Gastric Bypass: a Cohort Study from the Scandinavian Obesity Surgery Registry. Obes Surg. 2019 Jan;29(1):172-177.

3. Altieri MS, Pryor AD, Telem DA, Hall K, Brathwaite C, Zawin M. Algorithmic approach to utilization of CT scans for detection of internal hernia in the gastric bypass patient. Surg Obes Relat Dis. 2015 Nov-Dec;11(6):1207-11

4. Angrisani L, et al. Bariatric surgery and endoluminal procedures: IFSO Worldwide Survey 2014. Obes Surg. 2017;27:2279-89.

5. Arteaga-Gonzalez I, et al. Usefulness of clinical signs and diagnostic tests for suspected leaks in bariatric surgery. Obes Surg. 2015;25(9):1680-4.

6. Ayloo SM, Addeo P, Buchs NC, Shah G, Giulianotti PC. Robotassisted versus laparoscopic Roux-en-Y gastric bypass: is there a difference in outcomes? World J Surg. 2011;35:637-42.

7. Baumann AJ, Mramba LK, Hawkins RB, Carpenter AM, Fleisher MS, Ayzengart AL, Estores DS Jr. Endoscopic Dilation of Bariatric RNY Anastomotic Strictures: a Systematic Review and Meta-analysis. Obes Surg. 2018 Dec;28(12):4053-4063.

8. Bludau M, Hölscher AH, Herbold T, Leers JM, Gutschow C, Fuchs $\mathrm{H}$, Schröder W. Management of upper intestinal leaks using an endoscopic vacuum-assisted closure system (E-VAC). Surg Endosc. 2014 Mar;28(3):896-901. 
9. Camacho, D., \& Zundel, N. (Eds.). Complications in Bariatric Surgery. 2018

10. Carrodeguas L, Szomstein S, Soto F, et al. Management of gastrogastric fistulas after divided Roux-en-Y gastric bypass surgery for morbid obesity: analysis of 1,292 consecutive patients and review of literature. Surg Obes Relat Dis. 2005;1(5):467-74.

11. Carrodeguas L, Szomstein S, SotoF, et al. Management of gastrogastric fistulas after divided Roux-en-Y gastric bypass surgery for morbid obesity: analysis of 1,292 consecutive patients and review of literature. Surg Obes Relat Dis 2005;1:467-74

12. Chang J, Sharma G, Boulis M, Brethauer S, Rodriguez J, Endoscopic stents in the management of anastomotic complications after foregut surgery: new applications and techniques Surg Obes Relat Dis. 2016;12(7):1373-81

13. Chang SH, Stoll CR, Song J, Varela JE, Eagon CJ, Colditz GA The effectiveness and risks of bariatric surgery: an updated systematic review and meta-analysis, 2003-2012. JAMA Surg. 2014;149(3):275-287.

14. Cho M, Carrodeguas L, Pinto D, Lascano C, Soto F, Whipple O, Gordon R, Simpfendorfer C, Gonzalvo JP, Szomstein S, Rosenthal RJ. Diagnosis and management of partial small bowel obstruction after laparoscopic antecolic antegastric Roux-en-Y gastric bypass for morbid obesity. J Am Coll Surg. 2006;202(2):262-8.

15. Coblijn UK, Goucham AB, Lagarde SM, Kuiken SD, van Wagensveld BA. Development of ulcer disease after Roux-en-Y gastric bypass, incidence, risk factors, and patient presentation: a systematic review. Obes Surg. 2014;24(2):299-309.

16. Connor C, Thomas B, Pullatt R. Mesocolic Hernia: The Achilles Heel of the Retrocolic Gastric Bypass. Am Surg. 2015 Sep;81(9):e336-7. PMID: 26350651

17. Cooper TC, Simmons EB, Webb K, Burns JL, Kushner RF. Trends in weight regain following Roux-en-Y gastric bypass (RYGB) bariatric surgery. Obes Surg. 2015;25(8):1474-81

18. Corcelles R, Jamal MH, Daigle CR, Rogula T, Brethauer SA, Schauer PR. Surgical management of gastrogastric fistula. Surg Obes Relat Dis. 2015;11(6):1227-32.

19. Csendes A, Burgos AM, Braghetto I. Classification and management of leaks after gastric bypass for patients with morbid obesity: a prospective study of 60 patients. Obes Surg. 2012;22(6):855-62

20. Csendes A, Burgos AM, Altuve J, Bonacic S. Incidence of marginal ulcer 1 month and 1 to 2 years after gastric bypass: a prospective consecutive endoscopic evaluation of 442 patients with morbid obesity. Obes Surg. 2009;19(2):135-8.

21. Da Costa M, Mata A, Espinós J, Vila V, Roca JM, Turró J, Ballesta C. Endoscopic dilation of gastrojejunal anastomotic strictures afte laparoscopic gastric bypass. Predictors of initial failure. Obe Surg. 2011 Jan;21(1):36-41. doi: 10.1007/s11695-010-0154-7. PMID: 20396992.

22. Da Silva FB, Gomes DL de Carvalho KM. Poor diet quality and postoperative time are independent risk factors for weight regain after Roux-en-Y gastric bypass. Nutrition. 2016;32(11-12):1250-3.

23. Davis PJ, Liu RY, Haardt D, Ellsmere J. Robotic versus laparoscopic Roux-en-Y gastric bypass (RYGB) in obese adults ages 18 to 65 years: a systematic review and economic analysis. Surg Endosc. 2014;28(2):414-26

24. DeMaria EJ, Pate V, Warthen M, Winegar DA. Baseline data from American Society for Metabolic and Bariatric Surgery-designated Bariatric Surgery Centers of Excellence using the Bariatric Outcomes Longitudinal Database. Surgery for Obesity and Related Diseases. 2010;6(4):347-355.

25. El-Hayek K, Timratana P, Shimizu H, Chand B. Marginal ulcer after Roux-en-Y gastric bypass: what have we really learned? Surg Endosc. 2012;26(10):2789-96.

26. El-Kadre L, et al. Overcoming the learning curve of laparoscopic Roux-en-Y gastric bypass: a 12-year experience. Surg Obes Relat Dis. 2013;9(6):867-72.

27. Felix EL, Kettelle J, Mobley E, Swartz D. Perforated marginal ulcers after laparoscopic gastric bypass. Surg Endosc. 2008;22(10):2128-32

28. Fernandez AZ JrDeMaria EJTichansky DS et al. Experience with over 3,000 open and laparoscopic bariatric procedures: multivariate analysis of factors related to leak and resultant mortality. Surg Endosc 2004;18 (2) 193-197.

29. Fernandez-Esparrach G, Lautz DB, Thompson CC. Endoscopic repair of gastrogastric fistula after Roux-en-Y gastric bypass: a less-invasive approach. Surg Obes Relat Dis 2010;6(3):282-8.

30. Filho AJ, Kondo W, Nassif LS, Garcia MJ, Tirapelle Rde A, Dotti CM. Gastrogastric fistula: a possible complication of Roux-en-Y gastric bypass. JSLS. 2006;10(3):326-31.

31. Fridman A, Szomstein S, Rosenthal RJ. Postoperative bleeding in the bariatric surgery patient. In: Nguyen NT, Blackstone RP, Morton JM, Ponce J, Rosenthal RJ, editors. The ASMBS textbook of bariatric surgery: volume 1: bariatric surgery. New York: Springer Science+Business Media; 2015
32. GBD 2017 Risk Factor Collaborators. Global, regional, and national comparative risk assessment of 84 behavioural, environmental and occupational, and metabolic risks or clusters of risks for 195 countries and territories, 1990-2017: a systematic analysis for the Global Burden of Disease Study 2017. The Lancet. 8 Nov 2018;392:1923-94.

33. Geubbels N, Lijftogt N, Fiocco M, van Leersum NJ, Wouters MW, de Brauw LM. Meta-analysis of internal herniation after gastric bypass surgery. Br J Surg. 2015;102(5):451-60.

34. Goitein D, Papasavas PK, Gagné D, Ahmad S, Caushaj PF. Gastrojejunal strictures following laparoscopic Roux-en-Y gastric bypass for morbid obesity. Surg Endosc. 2005;19(5):628-32

35. Green J, Ikuine T, Hacker S, Urrego H, Tuggle K. Acute small bowel obstruction due to a large intraluminal blood clot after laparoscopic Roux-en-Y gastric bypass. J Surg Case Rep. 2016;2016(8):rjw143. Published 2016 Aug 23. doi:10.1093/jscr/ rjw143.

36. Heneghan HM, Meron-Eldar S, Yenumula P, Rogula T, Brethauer SA, Schauer PR (2012) Incidence and management of bleeding complications after gastric bypass surgery in the morbidly obese. Surg Obes Relat Dis 8:729-735.

37. Joo MK. Endoscopic Approach for Major Complications of Bariatric Surgery. Clin Endosc. 2017 Jan;50(1):31-41. doi: 10.5946/ ce 2016.140. Epub 2016 Dec 23. PMID: 28008162; PMCID: PMC5299989.

38. Iannelli A, Facchiano E, Gugenheim J. Internal hernia after laparoscopic Roux-en-Y gastric bypass for morbid obesity. Obes Surg 2006; 16:1265-71

39. Kalaiselvan R, Exarchos G, Hamza N, Ammori BJ. Incidence of perforated gastrojejunal anastomotic ulcers after laparoscopic gastric bypass for morbid obesity and role of laparoscopy in their management. Surg Obes Relat Dis. 2012;8:423-8.

40. Kane ED, Romanelli JR. Complications of Roux-en-Y gastric bypass. In: Reavis KM, Barrett AM, Kroh MD, editors. The SAGES manual of bariatric surgery. Cham: Springer International Publishing; 2018. p. 403-29.

41. Khalayleh H, Pines G, Imam A, Sapojnikov S, Buyeviz V, Mavor E. Anastomotic Stricture Rates Following Roux-en-Y Gastric Bypas for Morbid Obesity: A Comparison Between Linear and CircularStapled Anastomosis. J Laparoendosc Adv Surg Tech A. 2018 Jun;28(6):631-636.

42. Kim J, et al. ASMBS position statement on prevention, detection, and treatment of gastrointestinal leak after gastric bypass and sleeve gastrectomy, including the roles of imaging, surgical exploration, and nonoperative management. Surg Obes Relat Dis 2015;11(4):739-48

43. Kravetz AJ, Reddy S, Murtaza G, Yenumula P. A comparative study of handsewn versus stapled gastrojejunal anastomosis in laparoscopic Roux-en-Y gastric bypass. Surg Endosc. 2011;25:1287-92.

44. Kumar N, Thompson CC. Transoral outlet reduction for weight regain after gastric bypass: long-term follow-up. Gastrointest Endosc. 2016;83(4):776-9

45. Lauti M, Stevenson S, Hill AG, MacCormick AD. Patient perspectives about follow-up care and weight regain following sleeve gastrectomy. Obes Surg. 2016;26(11):2724-31

46. Lee JK, Van Dam J, Morton JM, Curet M, Banerjee S. Endoscopy is accurate, safe, and effective in the assessment and management of complications following gastric bypass surgery. Am J Gastroenterol 2009; 104:575-582.

47. Livhits M, Mercado C, Yermilov I, Parikh JA, Dutson E, Mehran A et al. Patient behaviors associated with weight regain after laparoscopic gastric bypass. Obes Res Clin Pract. 2011;5(3):e169-266.

48. Livingston $\mathrm{EH}$. The incidence of bariatric surgery has plateaued in the U.S. Am J Surg. 2010;200(3):378-385.

49. Magro DO, Geloneze B, Delfini R, Pareja BC, Callejas F, Pareja JC. Long-term weight regain after gastric bypass: a 5-year prospective study. Obes Surg. 2008;18(6):648-51.

50. Maleckas A, Gudaityte R, Petereit R, Venclauskas L, Velickiene $D$. Weight regain after gastric bypass: etiology and treatment options. Gland Surg. 2016;5(6):617-24.

51. Meguid MM, Glade MJ, Middleton FA. Weight regain after Rouxen-Y: a significant $20 \%$ complication related to PYY. Nutrition. 2008;24(9):832-42.

52. Mickevicius A, Sufi P, Heath D. Factors predicting the occurrence of a gastrojejunal anastomosis leak following gastric bypass. Wideochir Inne Tech Maloinwazyjne. 2014;9(3):436-40.

53. Nelson LG, Gonzalez R, Haines K, Gallagher SF, Murr MM. Spectrum and treatment of small bowel obstruction after Roux-en-Y gastric bypass. Surg Obes Relat Dis. 2006 May-Jun;2(3):377-83, discussion 383. doi: 10.1016/j.soard.2006.02.013. PMID: 16925356

54. Nguyen NT, Hinojosa MW, Gray J, Fayad C. Reoperation for marginal ulceration. Surg Endosc. 2007;21(11):1919-21. 
55. Niland B, Brock A. Over-the-scope clip for endoscopic closure of gastrogastric fistulae. Surg Obes Relat Dis. 2017;13(1):15-20.

56. Obeid A, McNeal S, Breland M, Stahl R, Clements RH, Grams J. Internal hernia after laparoscopic Roux-en-Y gastric bypass. J Gastrointest Surg. 2014 Feb; 18(2):250-5; discussion 255-6.

57. O'Rourke RW. Management strategies for internal hernia after gastric bypass. J Gastrointest Surg. 2011;15(6):1049-54.

58. Patel RA, Brolin RE, Gandhi A.Revisional operations for marginal ulcer after Roux-en-Y gastric bypass. Surg Obes Relat Dis 2009; 5:317-22.

59. Pazouki A, Pakaneh M, Khalaj A, Tamannaie Z, Jangjoo A, Shapoori P, et al.. Blood bezoar causing obstruction after laparoscopic Rouxen-Y gastric bypass. Int J Surg Case Rep 2014;5:183-5.

60. Puig CA, Waked TM, Baron TH Sr, Wong Kee Song LM, Gutierrez J, Sarr MG. The role of endoscopic stents in the management of chronic anastomotic and staple line leaks and chronic strictures after bariatric surgery. Surg Obes Relat Dis. 2014 JulAug;10(4):613-7. doi: 10.1016/j.soard.2013.12.018. Epub 2014 Jan 11. PMID: 24680763

61. Ribeiro-Parenti L, De Courville G, Daikha A, Arapis K, Chosidow D, Marmuse JP. Classification, surgical management and outcomes of patients with gastrogastric fistula after Roux-En-Y gastric bypass. Surg Obes Relat Dis. 2016;

62. Riva P, Perretta S, Swanstrom L. Weight regain following RYGB can be effectively treated using a combination of endoscopic suturing and sclerotherapy. Surg Endosc. 2017;31(4):1891-5.

63. Salimath J, Rosenthal RJ, Szomstein S. Laparoscopic remnant gastrectomy as a novel approach for treatment of gastrogastric fistula. Surg Endosc. 2009;23(11):2591-5.

64. Santo MA, Riccioppo D, Pajecki D, Kawamoto F, de Cleva R, Antonangelo L, et al. Weight regain after gastric bypass: influence of gut hormones. Obes Surg. 2016;26(5):919-25.

65. Schiesser M, et al. Successful endoscopic management of gastrointestinal leakages after laparoscopic Roux-en-Y gastric bypass surgery. Dig Surg. 2014;31(1):67-70.
66. Shikora SA. The use of staple-line reinforcement during laparoscopic gastric bypass. Obes Surg 2004;14:1313-20.

67. Simillis C, Fachiri M, Bonanomi G. A challenging gastrointestinal hemorrhage after gastric bypass treated with interventional radiology. Surg Obes Relat Dis. 2016;12(7):e59-62.

68. Souto-Rodriguez R, Alvarez-Sanchez MV. Endoluminal solutions to bariatric surgery complications: a review with a focus on technical aspects and results. World J Gastrointest Endosc. 2017;9(3):105-26.

69. Spector D, Perry Z, Shah S, Kim JJ, Tarnoff ME, Shikora SA. Rouxen-Y gastric bypass: hyperamylasemia is associated with small bowel obstruction. Surg Obes Relat Dis. 2015;11(1):38-43.

70. Tamboli RA, Breitman I, Marks-Shulman PA, Jabbour K, Melvin W, Williams B, et al. Early weight regain after gastric bypass does not affect insulin sensitivity but is associated with elevated ghrelin. Obesity (Silver Spring). 2014;22(7):1617-22.

71. Tran DD, Nwokeabia ID, Purnell S, Zafar SN, Ortega G, Hughes K, et al. Revision of Roux-En- Y gastric bypass for weight regain: a systematic review of techniques and outcomes. Obes Surg. 2016;26(7):1627-34.

72. Wernick B, Jansen M, Noria S, Stawicki SP, El Chaar M. Essential bariatric emergencies for the acute care surgeon. Eur J Trauma Emerg Surg. 2016;42(5):571-84.

73. Uchima H, Abu-Suboh M, Mata A, Cruz M, Espinos J. Lumenapposing metal stent for the treatment of refractory gastrojejunal anastomotic stricture after laparoscopic gastric bypass. Gastrointest Endosc. 2016;83(1):251

74. Yanos BR, Saules KK, Schuh LM, Sogg S. Predictors of lowest weight and long-term weight regain among Roux-en-Y gastric bypass patients. Obes Surg. 2015;25(8):1364-70.

75. Zafar SN, Miller K, Felton J, Wise ES, Kligman M. Postoperative bleeding after laparoscopic Roux en Y gastric bypass: predictors and consequences. Surg Endosc. 2019 Jan;33(1):272-280.

\section{Ранні та пізні ускладнення після шунтування шлунка. Огляд літератури}

\section{В. О. Невмержицький}

Національний медичний університет імені О. О. Богомольця, Київ

Ожиріння та надмірна маса тіла вже протягом багатьох років є важливою суспільною проблемою. За даними ВОО3, близько 1,9 мільярда людей старше 18 років мають надмірну масу тіла. Близько 4,7 мільйонів людей в 2017 році померли передчасно внаслідок ожиріння. Глобально смертність від ожиріння зросла 3 4,5\% в 1990 році до 8\% в 2017 році. Баріатрична хірургія на сьогодні визнана найбілыш ефективним методом лікування морбідного ожиріння. Серед баріатричних оперативних втручань за останніх 10 років, шлункове шунтування підтвердило свою ефективність через оптимальний метаболічний ефект.

Мета огляду - провести аналіз даних літератури для визначення основних ускладнень після шлункового шунтування у хворих з ожирінням.

За даними оглядку літератури, кількість ускладнень після баріатричних операцій зменшилась 3 10,5\% в 1993 до 7,6\% в 2006. Рівень смертності після баріатричних втручань становить 0,08\% в перші 30 днів після операціï, і 0,31\% після 30 днів. За результатами дослідження BOLD (2010) серед 57918 баріатричних втручань рівень ускладнень становив 6240 (10,77\%), а рівень летальності - 78 (0,135\%), протягом 30 днів після втручання - 0,089\%, протягом 90 днів - 0,112\%. Для гастрошунтування за Ру (30 864 втручання) рівень ускладнень був 4588 (14,87 \%). До ранніх ускладнень належать - неспроможність анастомозу (0-5,6\% для лапароскопічного доступу, та 1,6-2,6\% для лапаротомічного), обтураційна кишкова непрохідність кров'яним згустком (0-0,5\%), кровотеча з ділянки швів (1,5\%), тромбемболічні ускладнення (0,2-5\%). До пізніх ускладнень - стеноз ділянки шлунково-кишкового тракту (3-27\%), маргінальна виразка - 0,6-16\%, защемлена внутрішня грижа (грижа Петерсена) - 2,51\%, перфорація стінки шлунка та тонкої кишки $(1-2 \%)$, шлунково-шлункова нориця - 1,5-6,0\%, рецидив морбідного ожиріння (до 17,1%).

Таким чином, враховуючи світову тенденцію збільшення кількості баріатричних операцій, на часі - вирішення питання можливих їх ускладнень. Через це, необхідним є пошук нових ефективних методів профілактики та лікування ускладнень після хірургічного лікування пацієнтів з ожирінням.

Ключові словА: ожиріння, баріатричні операції, шлункове шунтування, неспроможність анастомозу, обтураційна кишкова непрохідність, маргінальна виразка, грижа Петерсена, шлунково-шлункова нориця, рецидив ожиріння.

F O R C I T A T I O N

I Nevmerzhytskyi VO. Early and late complications after gastric bypass: A literature review. General Surgery (Ukraine). 2021:1;60-66. http://doi.org/10.30978/GS-2021-1-60. 